\title{
Åland Islands: lessons for the conflict of the Falkland Islands (Malvinas Islands)?
}

\author{
S. G. Eissa \\ Universty of Buenos Aires, \\ Ayacucho 1245 (C1111AAI), Buenos Aires, Argentina
}

For citation: Eissa S. G. Åland Islands: lessons for the conflict of the Falkland Islands (Malvinas Islands)? Vestnik of Saint Petersburg University. International Relations, 2019, vol. 12, issue 2, pp. 210 228. https://doi.org/10.21638/11701/spbu06.2019.207

Falkland Islands (Malvinas Islands) are not on the agenda of the Mauricio Macri's government (2015-2019) and were, on the contrary, a key issue during the governments of Néstor Kirchner (2003-2007) and Cristina Fernández de Kirchner (2007-2015). However, it can be argued that the conflict over sovereignty between Argentina and Great Britain has not been a priority of the governmental agenda since the end of the Malvinas War (1982). This means that Argentina's foreign policy has lacked creativity and realism with respect to the conflict and has chosen to continue making formal presentations within the framework of the United Nations so as not to affect commercial interests in the relationship between the two countries; or to carry out theatrical unilateral measures to use the conflict to obtain votes in internal political dynamics, manipulating to Argentine nationalist feelings. Firstly, the present article analyzes the main historical and strategic aspects of the conflict around the Malvinas Islands. Subsequently, the resolution of the dispute between Sweden and Finland over the sovereignty of the Åland Islands is reviewed. Finally, there are some reflections on what could be a third way for Argentina's foreign policy belong to this problem.

Keywords: Malvinas Islands, Falkland Islands, Åland Islands, Argentina, United Kingdom.

\section{Introduction}

The Malvinas, Georgia and the Southern Sandwich Islands (Falklands Islands) ${ }^{1}$ have been irrelevant in the government agenda of the Argentine Republic. That is, most Argentinian politicians in that country do not want to address the question of sovereignty for the resolution of the conflict. On the one hand, the dispute with the United Kingdom of Great Britain and Northern Ireland (from now on the United Kingdom) for the Falkland Islands (Malvinas Islands) is a symbol that is used in the framework of the domestic political dispute to attract votes by appealing to the nationalist and anti-imperialist feelings that is still strong in Argentine society. In a recent survey conducted for this article, $47.2 \%$ of those interviewed in the Metropolitan Area of Buenos Aires considered that the Argentine government should put pressure on the United Kingdom to negotiate with Argentina ${ }^{2}$. On

${ }^{1}$ The Malvinas Islands denomination in Spanish and the Falkland Islands in English will be used to refer to these islands, the Georgia Islands and the South Sandwiches Islands.

2 The Electoral Monitor is carried out since May 2018 in AMBA (24 Municipalities of Greater Buenos Aires and the Autonomous City of Buenos Aires). This measurement was made between October 5 and 7 , 2018 and was 1,265 effective cases. The collection was carried out by telephone with IVR technology (inter-

(c) Санкт-Петербургский государственный университет, 2019 
the other hand, a former national deputy, currently an official of the current government, stated, in the framework of another investigation [1], that he considered that the Falkland Islands (Malvinas Islands) should be divided in two, one half for Argentina (the most depopulated and closer to the continent) and the other for the United Kingdom. In that way, he considered, Argentina would end up limiting with the European Union. However, he clarified in that interview in off that he would never make this proposal public and categorically deny having formulated it because it would be the end of his political career. Consequently, both those who claim to support the "cause of the Malvinas", appealing to Argentine nationalism and anti-imperialism, and those who prefer to leave the issue out of the agenda to improve the relationship in the United Kingdom and, consequently, to keep the business climate with that country; they prefer to maintain the status quo, that is, to continue making the claim in the United Nations, knowing that this international organization will not resolve the sovereignty dispute. It is a non-state policy.

The oscillation between these two positions, which in my opinion maintain the status quo of the conflict between the two countries, can be explained from the thesis pointed out by José Paradiso in the 1990s [2, p. 15]. The form of insertion of Argentina in the world economy system would explain the changes in the main guidelines of Argentine foreign policy. In this way, it is understood that sovereignty dispute has never been transformed into a hypothesis of conflict for the Argentine Armed Forces because United Kingdom was the Argentine's main trading partner from the mid-nineteenth century until the 30s of the 20th century in of the agro-export development model [3] $]^{3}$. Therefore, also the main achievements in relation to the sovereign dispute were made during the governments of Juan Domingo Perón (1946-1952, 1952-1955 and 1973-1974), Arturo Humberto Illia (1963-1966) and Cristina Fernández de Kirchner (2007-2015); that is, in the context of the import substitution industrialization (ISI) development model.

Thus, it can be predicted that the government of Mauricio Macri (2015-2019), and if reelected in the general elections of October 2019, will not produce any change in its policy towards the United Kingdom: Falkland Islands (Malvinas Islands) will continue outside of the government's agenda with the hope that British investments to flow to Argentina so as to sustain the financial valuation model. In this way, it will grant what the British request with respect to the islands - for example, additional flights - without reaching any agreement regarding the sovereignty dispute.

The problem is that the world that Mauricio Macri imagined, liberal democracies and more globalization, is in transition. As Andrés Malamud maintains:

It is a world in transition. The world that Macri liked is the world of liberal democracies played by Barack Obama. The world that Cristina [Fernández de Kirchner] thought we were addressing is the world opposed to the Western world, of the emerging powers led by China.

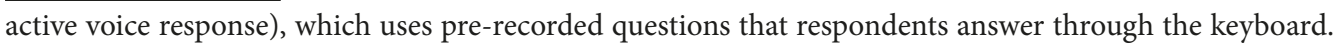
The selection of households was made from a sample of landlines. Subsequently, the results were adjusted by parameters of regions, census strata, socioeconomic characteristics of households, sex, age and educational level. The resulting margin of error (for $\mathrm{p}=0.50$ and below a confidence level of $95.5 \%$ ) varied between $+/-3.1 \%$ and $2.6 \%$ according to the measurement. DICEN Consultant, Buenos Aires.

3 The plan of the last dictatorship (1976-1983) to recover the Malvinas Islands began to be drawn up in November 1981. Despite this, the plan was not completed and "Operation Rosario" had to be anticipated due to disputes within the government between each of the Armed Forces. In addition, the Argentinian academics distinguish three economic models: a) agroexport (1860-1930); b) industrialization by import substitution (1930-1975); y c) financial valorization (1975-2003) [3]. 
As the world is now, Cristina Kirchner is closer to the future than Macri. There is no longer any doubt that Macri was wrong to diagnose, because the world is no longer [Donald] Trump's. But he was lucky that the American president financed it. That is to say, the world that Macri did not want to reach is the one that has it in the pulmotor [4].

In spite of the changes that have taken place in the world, as well as the problems that the United Kingdom is facing, both in terms of budget cuts [5-7] and the exit of that country from the European Union (Brexit) [8], are not appreciated by Argentina as an opportunity to produce a substantial change in their policy towards the Falkland Islands (Malvinas Islands); argentinian politicians have not promoted the rise of this issue on the agenda of both countries.

Likewise, strategic resources have revalued geopolitical spaces. As Klare points out clearly:

While in the era of the Cold War divisions were created and alliances were formed following ideological guidelines, at present economic competition governs international relations and, therefore, competition for access to these vital economic riches has intensified [9, p. 1].

Following this line of argument, it is clear that the Malvinas-Atlántico Sur-Antarctica system [10] possesses invaluable strategic resources, such as fresh water, fish, mineral, energy resources, the gateway to Antarctica, to mention just a few, which returned to place the islands in the strategic priority of the United Kingdom. In spite of the fact that there is a big difference, in terms of power capabilities between the United Kingdom and Argentina, the dispute over the strategic resources in that systemic area between the powers and the potential exit of the Great Britain from European Union, make up a unique scenario to find a solution to this protracted conflict.

So, where can we find lessons to produce a substantial change in Argentine foreign policy towards the Falkland Islands (Malvinas Islands)?

There are few articles that had compared the case of the Falkland Islands (Malvinas Islands) with other colonial cases, whose colonies belong to the United Kingdom of Great Britain. Briefly, some studies make a comparison with the case of Hong Kong [11; 12]. Robert Laver analyzes the cases of Hong Kong, the Åland Islands and Andorra - as a precedent of shared sovereignty [13]. For his part, Chris Kozloski argues that the irresolution of the conflict is due to the nationalist positions of at least one of the parties [14]. To this end, he notes, also mentioning the Åland Islands, which

Currently, there are many future plans that attempt to solve the Falkland Island problem. I will not go into detail as each of these is worth many articles by itself, but the solutions range from a Fortress Falklands, the current policy, to Integration of the islands with Britain, Independence, A NATO or SATO-Based Multilateral security council to govern the island, UN Trusteeship, Inclusion of the islands in the Antarctic Treaty, taking the case to the International Court, a British-Argentinean condominium, Shared Dual Sovereignty, Lease back with Guarantees, Sovereignty Freeze, Abandonment, and finally, Titular Sovereignty and Autonomy based on the Åland Island model [11, p. 646; 12, p. 143-160]. The most promising plan to date is the Lease back with guarantees option.

In this same line of Laver's research, Jorge Emilio Nuñez [15] also studied the feasibility of the shared sovereignty of the Falkland Islands (Malvinas Islands) between Argentina and the United Kingdom. 
Marcelo Kohen [16] was one of the first to exhaustively analyze the case of the Åland Islands, after reviewing other alternatives such as Free Associated State, Lease-Back, Condominium and Protectorate, as the already mentioned case of Andorra. Finally, Peter Willets points out which

The Åland Islands provide a model for limited integration of the Islands with Argentina, with a degree of autonomy that is close to independence. This was considered seriously as a possible option by the Argentine government, when Guido di Tella was the Foreign Minister, but the current level of conflict makes it unacceptable to the Islanders [17, p. 1].

Donald Bullock and Christopher Mitchel [18] also study the case of the Åland Islands as a possible model to solve the conflict between Argentina and the United Kingdom of Great Britain ${ }^{4}$. This article follows this line of research.

Firstly, this article will analyze the conflict between Argentina and the United Kingdom over the Falkland Islands (Malvinas Islands). Secondly, it will be studied the case of the Åland Islands, whose sovereignty was disputed by Sweden, the Russian Empire and Finland between the $19^{\text {th }}$ and $20^{\text {th }}$ centuries. Finally, some final reflections are presented on the differences between both conflicts and on what lessons can be learned from the first one so that Argentina can redesign its foreign policy in this new world order that is being configured.

\section{Background to the dispute over the Falkland Islands (Malvinas Islands)}

The Falklands Islands (Malvinas Islands) are located in the South Atlantic, $356.4 \mathrm{~km}$ from the continental territory of the Argentine Republic and they cover an area of land of $15,266 \mathrm{~km}^{2}$ and with a population of 3,180 inhabitants. They were occupied militarily by the United Kingdom of Great Britain and Northern Ireland on 3 January 1833, expelling the governor of the Argentine Confederation, José María Pinedo (1832-1833). Since then the Argentine Republic has not ceased to claim sovereignty over the islands.

The discovery is disputed by Spaniards and Englishmen. However, some authors maintain that Amerigo Vespucci was the one who discovered the islands in 1502 [20, p. 259]. For its part, Spain argues that the islands were sighted by Esteban Gómez in 1522, to the command of the ship San Antonio, which was part of the expedition of Fernando de Magallanes. Although, the geographer Alonso de Santa Cruz awards the discovery of the islands to the ship Victoria, belonging to the same expedition, and that would have baptized the archipelago as Islas Samson and Los Patos [21]. On the other hand, the British argue that it was John Davies who discovered the islands on 14 August 1592 and/or Richard Hawkins on 2 February 1594. For his part, the expedition of John Strong would have traveled the islands and discovered the channel that separates them on 27 January 1690, baptizing it as Falkland in homage to Lucius Carey, Visconde of Falkland [22] ${ }^{5}$.

In the interim, the islands would have been visited by the Dutch Sebald de Weert on 24 January 1609, naming them the Sebaldine Islands. Likewise, the Frenchmen maintain that Captain Brignon, commanding the ship Notre-Dame de I'Incarnation, would have

${ }^{4}$ There are others researchs who compares the Falkland Islands (Malvinas Islands) and Åland, but they have different research goals. See [19, p.320].

${ }^{5}$ There were other expeditions to which the discovery and/or visit to the Malvinas Islands were awarded. See [22; 23]. 
traveled the islands in 1711 or 1716 (according to the source), calling them the New Islands or Malouines Islands [22; 23].

No matter who discovered them, the certainty is that the Falkland Islands (Malvinas Islands) were occupied successively by the France $(1764)^{6}$, United Kingdom $(1765)^{7}$ and Spain $(1767)^{8}$. In 1766, France recognized Spanish sovereignty over the islands and abandoned Fort Saint-Louis, which had been founded on 17 March 1764; which was renamed by the Spaniards as Puerto Soledad. In January of 1765, the United Kingdom had left a provisional and secret establishment on the Saunders Island (Isla Trinidad), until John McBride definitively founded Port Egmont on 8 January 1766. On 25 February 1768, the King of Spain ordered that all British settlements that were in the territories of the Spanish crown should be evicted. From this last year, Spain and the United Kingdom clashed for the possession of the islands, including militarily on 10 June 1770 in Port Egmont. After that British reoccupied it, both countries agreed to dismantle the port on 23 April 1774. After these facts, the stories and dates differ. The United Kingdom maintains that the abandonment of said port did not mean the renunciation of sovereignty and that they left signs and marks that the archipelago belonged to His Britannic Majesty [21]. On the other hand, Spain sustains that in the Declaration of Masserano-Rochford of 22 January 1771, both countries agreed to restore the status quo prior to the combat for the sole purpose of repairing the offense what did not affect in any way the Spanish sovereignty over the Falkland Islands (Malvinas Islands) [24], which was not objected by the British government. Also, Spain explains that British forces abandoned Port Egmont under a secret pact between the two countries on 22 May 1774 [25]. Finally, the United Kingdom recognized Spanish sovereignty through the Nutka Convention of $1790^{9}$, which passed into the hands of the United Provinces of the Río de la Plata ${ }^{10}$ in 1816 under the principle uti possidetis $[27 ; 28]^{11}$.

In 1820, the Government of the Province of Buenos Aires, in charge of the external relations of the United Provinces, sent a frigate to the Falkland Islands (Malvinas Islands) to reaffirm their rights over them. On 6 November of that year, Navy Officer David Jewett ${ }^{12}$ took possession of the islands on behalf of the United Provinces of the Río de la Plata

${ }^{6}$ Antoine Louis de Boungainville founded the Fort Royal or Fort Saint-Louis on March 17, 1764 [22].

${ }^{7}$ John McBride founded Port Egmont on the Saunders Island (Trinidad Island) on January 8, 1766 [22].

8 The appointed Spanish governor Felipe Ruiz Puente renamed the establishment as Puerto Soledad [23].

${ }^{9}$ In a letter dating from 1767, discovered in 2017, the first Spanish governor of the Falkland Islands (Islas Malvinas), Felipe Ruiz Puente, "mentioned the need to have a chapel and elements to put it into operation in Malvinas. The letters reveal that the governor of Buenos Aires sends the sacred vessels and ornaments to erect a new chapel in said "colony" as well as an image of the Virgin of Solitude, to be declared patron saint of the population [26]. The Islands were uninhabited by Spaniards in 1811.

${ }^{10}$ The successive denominations of the present Argentine Republic were: United Provinces of South America (1816-1824), United Provinces of the River Plate (1810-1816 and 1824-1829), Argentine Confederation (1829-1853) and since then Argentine Republic (Approximate dates). Although article 35 of its Constitution maintains: "The denominations adopted successively from 1810 to the present, namely: United Provinces of the Río de la Plata, Argentine Republic, Argentine Confederation, will henceforth be official names indistinctly for the designation of the Government and territory of the provinces, using the words Nación Argentina in the formation and sanction of laws". Consult in http://servicios.infoleg.gob.ar/infolegInternet/anexos/0-4999/804/norma.htm.

11 "The possession by legal use is based on the occupation of the territory based on legal title, which allows border conflicts to be resolved through international treaties" [28, p. 131].

12 Argentine Governors: David Jewett (1820-1821); Guillermo Mason (1821); Pablo Areguatí (18231824), Luis Vernet (1829-1831); Juan Esteban Francisco Mestivier (1832); José María Pinedo (1832-1833); Jean Simon (1833) [29]. 
in a public ceremony in Puerto Soledad, attended by witnesses of various nationalities. The news was published in newspapers in the United States and the United Kingdom without provoking official comments from those countries. Nor did Great Britain make any claim to the Falkland Islands (Malvinas Islands), nor did it make any safeguards when it signed the Treaty of Friendship, Commerce and Navigation of 1825 with Argentina [29]. On 10 June 1829, the "Political and Military Commandery of the Malvinas Islands and those adjacent to Cape Horn in the Atlantic Sea" was created, and Luis María Vernet (1829-1831) was appointed governor of the Islands [23]. Only on 19 November 1831, the British Government would raise a note of protest to the Argentine Confederation [29]. During that same year, on 27 December, the American corvette Lexington attacked the Argentine population that lived in the Islands ${ }^{13}{ }^{[29}$ ] and, as a consequence, the Argentine Confederation published on 14 February 1832 a proclamation committing itself to require a satisfaction, while protesting before the American consul [23, p.44, 22]. Taking advantage of this circumstance, on 3 January 1833 the United Kingdom, despite not being at war with the Argentine Confederation, attacked the Argentines who lived there and established a military garrison, forcibly evicting the Argentine settlers and authorities. On 17 June 1833, the plenipotentiary minister before the British Crown, Manuel Moreno, presented a protest note, which was renewed and extended on repeated occasions by the Argentine representative in London $[23 ; 24]^{14}$.

After 1833, Argentina made bilateral claims until the first half of the $20^{\text {th }}$ century, a strategy that was associated with the positioning of that country in the world capitalist economy as a "white" enclave of the British Empire [32]. Meanwhile, for the United Kingdom the islands were a strategic enclave, given that they allowed control of the Drake Passage. To such a point this statement is correct that on 8 December 1914 there was a naval battle between the German and British fleets.

From the second half of the $20^{\text {th }}$ century, the islands lost their strategic relevance for the United Kingdom. The claim of sovereignty ascended in the public agenda of Argentina, in consonance with the change of economic model, and promoted the initiatives that were carried out in the Pan-American Conference of Havana in 1940 and in the recently created United Nations. In this international organization, Resolution No. 2065/65 of the General Assembly of the United Nations (UN) was approved. This UN's rule, which was considered a success of the President Arturo Humberto Illia (1963-1966) and the Argentine Foreign Minister Miguel Ángel Zabala Ortiz (1963-1966), recognized the existence of a colonial situation and invited the parties to begin negotiations, supported in the principle of territorial integrity and not in the principle of self-determination, respecting the interests of the islanders (way of life).

In 1966, in a context in which the islands were strategically irrelevant to the British and in a situation of neglect of the needs of the population by the metropolis, formal negotiations between the United Kingdom and the Argentine Republic began. On 1 July 1971, the British Argentine Joint Declaration was signed on communications between the Falkland Islands (Malvinas Islands) and the Argentine mainland. Argentina commit-

${ }^{13}$ Luis Vernet arrived with fifty (50) settlers who joined those who lived there. At the time of the british attack, the population amounted to approximately one hundred and fifty (150) inhabitants (including the crew of the Sarandí Frigate [30].

14 The United States recognized independence on May 4, 1822; the United Kingdom of Great Britain on December 31, 1824 and the Kingdom of Spain on June 9, 1859 [31]. 
ted to establish an airline, which was in charge of LADE (Argentine State Airlines) with a biweekly service, which allowed travel between the islands and the mainland. An airstrip was built; two (2) Argentinian teachers went to the Islands to teach Spanish; and a scholarship program was implemented so that children of islanders could come to study and took them to the main english-speaking schools. In adddition, sick islanders were provided with transportation and free medical assistance at the British Hospital, although some residents preferred to be treated at the YPF Hospital in Comodoro Rivadavia. This agreement was fundamental because in June 1974, the British Government, through its embassy in Buenos Aires, proposed to Argentina a condominium on the islands that had clauses, among which stood out, that the Governor of the Islands would be designated alternatively for his Britannic Majesty and for the President of the Argentine Republic. The death of President Juan Domingo Perón, shortly after, frustrated the project that was withdrawn days later. On the same basis as the previous proposal, the British Government also proposed what was called the "leaseback" on the Malvinas Islands. A set of points was agreed upon, and the duration of the provisional administration of the islands to be exercised by the British government is still to be defined. There were a number of aspects that did not prosper in the British Parliament, but the negotiations continued and never, at least for the British official part, completely renounced that possibility [33].

After the Argentine defeat in the Falklands War in 1982, the Islands regained new strategic significance not only by the control of the bioceanic passes, but also by their projection on the Antarctic continent, the riches of the South Atlantic, among which they highlight the hydrocarbon deposits, fish resources and the existence of rare minerals in the maritime bed.

During the last two decades of the twentieth and the first one of the twentieth-one centuries, Argentina's policy around the Falkland Islands (Malvinas Islands) has been erratic. On the one hand, the first democratic government of Raúl Alfonsín (1983-1989) resumed the multilateral strategy by resorting to the General Assembly and the United Nations Decolonization Committee. On the other hand, and in the framework of the adoption of a neoliberal policy, President Carlos Menem (1989-1999) came back to a bilateral approach that sought an approach with Great Britain and with the islanders. As a result of these policies, Argentina and Great Britain signed the Agreement of Madrid I of October 19, 1989 that established the "umbrella of sovereignty"15 and the second, signed

${ }^{15}$ In said Agreement, a formula on sovereignty (known as the "Umbrella of Sovereignty") was agreed, which states that: "(1) Nothing in the development or content of the present meeting or any other similar meeting shall be construed as a) A change in the position of the Argentine Republic regarding the sovereignty or territorial and maritime jurisdiction over the Malvinas Islands (Falkland Islands), South Georgia and the South Sandwich Islands and the surrounding maritime areas; b) A change in the position of the United Kingdom regarding the sovereignty or territorial and maritime jurisdiction over the Falkland Islands (Malvinas Islands), South Georgia and the South Sandwich Islands and the surrounding maritime areas; c) A recognition or support of the position of the Argentine Republic or the United Kingdom regarding the sovereignty or territorial and maritime jurisdiction over the Falkland Islands (Malvinas Islands), South Georgia and the South Sandwich Islands and the surrounding maritime areas. (2) No act or activity carried out by the Argentine Republic, the United Kingdom or third parties as a consequence and in execution of what was agreed upon at this meeting or any other similar meeting may constitute grounds for affirming, supporting or denying the position of the Argentine Republic or the United Kingdom regarding the sovereignty or territorial and maritime jurisdiction over the Falkland Islands (Malvinas Islands), South Georgia and the South Sandwich Islands and the surrounding maritime area" [34, p.628]. 
on February 15, 1990, which modified the exclusion zone around to the islands that the British had established in 1982.

During the governments of Néstor Kirchner (2003-2007) and Cristina Fernández (2007-2015), the policy regarding the conflict in the Falkland Islands (Malvinas Islands) once again prioritized the multilateral forums and incorporated two new features [35]. First of all, the Argentine government adopted unilateral measures. In this line of action, when the Chilean company LATAM requested authorization to carry out charter flights between Punta Arenas and the Falkland Islands (Malvinas Islands) in 2003, the request was denied and, in exchange, the Argentine government offered direct flights between the continent and the islands, which was rejected by the British [36]. Also, the Argentine government protested in front of the European Union for the inclusion of the archipelago as an overseas area subject to the application of the European constitution ${ }^{16}$. In March 2007, the Argentine government terminated the oil exploitation cooperation agreement signed by former President Carlos Menem and, likewise, it was announced that the oil companies that are or had been operating in the disputed territories could not operate in the Argentine territory. At the beginning of 2010, Argentine President Cristina Kirchner signed Decree No 256/2010 whereby "any ship or naval artifact that intends to transit between ports located in the Argentine mainland and ports located in the Malvinas Islands, South Georgia and Sandwich del Sur must request a prior authorization issued by the competent national authority".

Secondly, Argentina sought to regionalize the conflict, seeking that both the Common Market of the South (MERCOSUR) and the South American Union of Nations (UNASUR) to adopt policies regarding the conflict ${ }^{17}$. On 29 June 2011, the MERCOSUR countries and their associate members reiterated "their support for the legitimate rights of the Argentine Republic in the sovereignty dispute over the question of the Falkland Islands (Malvinas Islands)". Also in this area it was agreed, on 20 December 2011, to prohibit ships sailing with "the flag of the Falkland Islands (Islas Malvinas)" to use the ports of this regional block. During the speech in which the Argentine president was named president pro tempore of MERCOSUR she pointed out that

We are not telling you to come to recognize us that the Malvinas Islands are Argentine; We are telling them to comply with what the United Nations said: sit down to talk, to dialogue, to dialogue [...] Finally, I want to thank especially the support you have given to Malvinas, which is not an Argentine cause. Malvinas is not an Argentine cause, it is a global cause, because in the Malvinas the oil and fishing resources are being taken away. And when they need more

16 This is not a minor issue because as overseas territories of "a Member State of the European Union, the Falkland (Malvinas) enjoy a special legal status according to the Treaties of Rome and Maastricht [...] it guarantees a free circulation of the goods that are produced there. As citizens of the United Kingdom, the natives of the islands can circulate and work throughout the EU territory (which is not reciprocal) and there is a quota for the free movement of people, as is the case with merchandise". Likewise, the Falkland Islands (Malvinas Islands) "receive funding from the European Commission through two channels. First, the islands received 4.2 million pounds (about 6.22 million euros) through STABEX (a system for stabilizing export earnings). Secondly, the European Development Fund (EDF), separated into regional and territorial funds, has contributed 700,000 euros for infrastructures that allow the development of their farms, and 3 million euros in territorial aid plus 1.5 million euros in regional aid". The islanders also meet every year with "the European Commission in the European Forum of Overseas Countries and Territories" [37].

17 To see more details, it is suggested to visit the following page consulted on June 24, 2018: http:// www.cuestionmalvinas.gob.ar/mercosur/. 
resources - everyone who has resources thinks - they have them by force, they are going to look for them wherever and however they may be [38].

The British government reacted with concern to this decision not to allow ships to enter the flag of the islands and therefore began to discuss "urgently" with the countries of the region. For his part, the Labor leader, Denis MacShane, said that "South American leaders know that the United Kingdom has fewer friends than ever because of Cameron's isolationist approach in Europe and the indifference towards the Obama administration" [39].

Finally, it should be noted that Law No. 26,875 (2013) was enacted that provides for the creation of the Namuncurá Marine Protected Area - Burdwood Bank, in the southern Argentine Sea, with the aim of demonstrating that Argentina also has the will to protect the environment promoting scientific research and the sustainable use of natural resources, trying to prevent the United Kingdom from using them in their own way. In that same intelligence, the Argentine government promoted the Pampa Azul initiative, which aims to "deepen scientific knowledge as a basis for conservation policies and management of natural resources; promote technological innovations applicable to the sustainable exploitation of natural resources and the development of industries linked to the sea; strengthen the maritime consciousness of Argentine society; and to support with information and scientific presence the sovereignty of our country in the South Atlantic area" [10, p. 13].

Despite this erratic policy, the second most important success of Argentine diplomacy began to take shape with the approval of Law No. 24,815 in 1997 that launched the National Commission of the Foreign Limit of the Continental Shelf (COPLA). Indeed, just over 50 years after the adoption of Resolution 2065. The Commission on the Limits of the Continental Shelf (CLPC) of the United Nations approved by consensus the Argentine recommendations, presented in 2009, regarding the external limit of the continental shelf, after ten years of work. The Commission did not rule on the limits in the Falkland Islands (Malvinas Islands), South Georgia and the South Sandwich Islands until Argentina and the United Kingdom resolve the border conflict, thereby recognizing the existence of the conflict of sovereignty [40]. On the other hand, it allows the South American country to expand business in terms of oil and on the riches of the seabed, while at the same time injecting uncertainty into the economic activities carried out by the United Kingdom in the waters of the South Atlantic [41]. Some analysts consider that the event was a new success of Argentine diplomacy, maybe, the most significant diplomatic success in Argentina since Resolution $2065^{18}$.

After the change of government on 10 December 2015, the debate on how to achieve the recovery of the Falkland Islands (Islas Malvinas) was rekindled in the public opinion because Mauricio Macri had said in 1997 that the islands would be an additional expenditure to Argentina. On the one hand, President Mauricio Macri [42] decided to return to a bilateral approach on the issue of sovereignty conflict [43]. On the other, and as noted by Foreign Minister Susana Malcorra, the Argentine government decided to prioritize the relationship with the United Kingdom in what it was considered a return to the West. In this sense, while the Argentine government decided - following the antecedent of the

18 To see more details it is suggested to visit the following page http://www.plataformaargentina.gov.ar/ es/la-comisi \%C3\%B3n-nacional-del-1\%C3\%ADmite-exterior-de-la-plataforma-continental-copla (accessed: 07.04.2016). 
administration of Carlos Menem - to put the conflict in an impasse and to advance in the strengthening of the bilateral relationship and in the humanitarian aspects related to the conflict. The United Kingdom sought to strengthen economic ties with Argentina and ensure the connectivity of the Falkland Islands (Malvinas Islands) with the continent, both in terms of the movement of people and commercially. This agreement is known as Foradori-Duncan [42]. These were vital for British before the perspective of the disconnection of the United Kingdom of the European Union (BREXIT). In this context, the British government obtained authorization from its Argentine counterpart for a new LATAM flight to be made from Brazil, stopping in the Argentine city of Córdoba, without passing through Buenos Aires, as requested by the islanders.

In this sense, the work carried out by the Red Cross for the identification of Argentine soldiers killed in the war was continued; and work is under way on the resumption of flights between the continent and the islands through companies that are not Argentine; the joint exploitation of resources in the South Atlantic [44]; and the lifting of sanctions so that Argentina can acquire certain spare parts and weapons systems in that country [45].

\section{Interests of the United Kingdom or the wishes of the Islanders?}

On 10 March 2013, the Legislative Assembly of the Islands called for a referendum to consult its "inhabitants" if they wished to remain a territory dependent on the United Kingdom of Great Britain and Northern Ireland. Once the result was known in favor of maintaining the current status quo, the Prime Minister, David Cameron, stated that "the Malvinas could not have been clearer. They want to remain British and that point of view should be respected by everyone, including Argentina" [46]. In this regard the Argentine Foreign Ministry argued that "the United Kingdom has no right to seek to alter the legal status of these territories, even with the disguise of the hypothetical referendum" and added that:

The Malvinas, South Georgia and South Sandwich Islands and the surrounding maritime areas are the subject of a sovereignty dispute between Argentina and the United Kingdom that has been recognized by those two countries and by the international community as a whole [...]. Instead of fulfilling its international obligations by resuming negotiations with Argentina to resolve this controversy, the British side - in a clear demonstration of the lack of grounds for its claims and above all lacking in good faith — seeks to introduce elements aimed at distorting [...] this vote, as well as the thousand queries or votes more than the United Kingdom could invent in the disputed territories included in the Malvinas Question, can not have that result nor relieve that country from complying with the obligation imposed by international law on it. peacefully resolve the sovereignty dispute it has with Argentina through the resumption of Negotiations [47].

Despite the above to the declaration of the Argentine Foreign Ministry, the use of the principle of self-determination allows Britain to obtain international legitimacy because, at least in the West, who would dare to say that a government must be "imposed" on the inhabitants of the Islands? However, on the one hand, this principle does not apply to the case of the Falkland Islands (Malvinas Islands) because it is an implanted population that evicted the Argentine population in 1833, as we have seen ut supra [48] On the other hand, the British position responds to its geopolitical interests that transcend the will of the population of the Falkland Islands (Malvinas Islands). As background, it can be 
pointed out that the 2 thousand inhabitants of Diego Garcia Island in the Indian Ocean were expelled by that country in 1971, for the purpose of renting it to the United States or, likewise, the opposition of the United Kingdom to the referendum in Crimea in 2014. In addition, the referendum does not change the status of the conflict in international organizations. In this regard, the United Nations, through its Decolonization Committee, and regardless of the outcome of the referendum, once again urged the governments of Argentina and the United Kingdom to resume negotiations for the sovereignty of the Falkland Islands (Malvinas Islands) [49].

Britain hides their true interests in the region behind the argument of the wishes of the islanders. Therefore, the key is to understand that the territorial dispute does not end in the Falkland Islands (Malvinas Islands), but extends throughout the South Atlantic to the South Pole. The Falkland (Malvinas) question and the Antarctic issue must be addressed in an integral way, without losing sight of the particularities of each of the regions, namely: the Falkland Islands (Malvinas Islands), the South Georgia Islands and South Sandwich Islands; the Antarctic Territory that includes the Orkney (Orcadas) and South Shetland Islands, which lie south of the $60^{\text {th }}$ parallel [10].

Firstly, the so-called "Antarctic Projection Fallacy" [10] must be taken into account. In general, the bibliography uses the term "Antarctic projection" to refer to one of the geopolitical motives of the Malvinas (Falklands) conflict. This vision proposes that whoever controls the Falkland Islands (Malvinas Islands), as well as the South Georgia and South Sandwich Islands, will have greater titles to claim their sovereignty over the Antarctic Peninsula and its surrounding waters. However, the British claims of sovereignty over Antarctica are not only linked to the Falkland Islands (Malvinas Islands). On the one hand, they provide the United Kingdom with a geopolitical advantage by hosting a military base in that archipelago as a "gateway" to the white continent. On the other hand, this base is the last link in a chain of archipelagos controlled by this European power, composed of the Islands of Ascension, Santa Helena and Tristán de Acuña, from where they can "control" the entire South Atlantic [10].

Secondly, South Georgia and South Sandwich Islands are within what is known as the "Antarctic Convergence", that is, an imaginary border that surrounds Antarctica where cold waters sink beneath the relatively warm waters of the sub-Antarctic zone. For this reason, although both archipelagos are north of the $60^{\circ} \mathrm{S}$ parallel, they are affected by the treaties of the Antarctic Treaty System that deal with the protection of natural resources and the environment, mainly by the Convention for the Conservation of Living Resources Antarctic Marines.

Thirdly, this integrality of the dispute can be observed in some of the decisions that the British have taken since the beginning of the $20^{\text {th }}$ century. For example, the denominations that the United Kingdom has granted to the region have varied in accordance with their interests in each era. Unaware that in 1904 Scotland had sold to the Argentine government the first Antarctic meteorological station located in the South Orkney Islands (Islas Orcadas), at which time Argentina maintains an uninterrupted presence in Antarctica; Great Britain annexed the South Georgian Islands, South Orkney Islands (Islas Orcadas), South Shetland and the northern part of the Antarctic Peninsula in 1908, known as San Martin Land (Graham Land), considering all these territories as "Falkland Islands Dependencies". At that time, it also included the waters of the South Atlantic south of the $50^{\circ} \mathrm{S}$ parallel and to the South Pole, between the $20^{\circ}$ and $80^{\circ} \mathrm{O}$ meridians, that is to say, 
the sector that includes the Argentine and Chilean reclamation. In 1917, a new British patent letter clarified that the sectors north of the $58^{\text {th }} \mathrm{S}$ parallel and west of the $50^{\text {th }} \mathrm{O}$ were excluded from the claim. In 1962, after the entry into force of the Antarctic Treaty, the British government decided regroup their territories creating a special administration for the Antarctic territories - those under the $60^{\text {th }}$ parallel - called "British Antarctic Territories", leaving only the South Georgia and South Sandwich Islands as "Falkland Islands Dependencies". In 1985, these two archipelagos were considered by the United Kingdom as a new "overseas territory", different from that of the Falkland Islands (Malvinas Islands), a situation that continues to this day. It is important to note that these archipelagos do not have a permanent population, so the United Kingdom can not justify its claims on this territory based on the right of self-determination of peoples.

The British interests in the South Atlantic, the control of the Drake Passage and Antarctica and not the self-determination of the islanders are what justify their stay in the Falkland Islands (Malvinas Islands). Argentina must move in a direction that takes these premises into account. Where do you grasp some guidelines for designing a foreign policy towards the Falkland Islands (Islas Malvinas) that addresses the substantial issue: sovereignty.

\section{Lessons from the Åland Islands?}

\section{a) Historical-political analysis}

The Åland Islands has a land area of $1,552 \mathrm{~km}^{2}$, which is located at the entrance to the Gulf of Bothnia between Finland and Sweden, and in which 28,500 people live. These small islands tell us a surprising story that reflects the dispute between the European powers. Until 1809 they belonged to Sweden, between that date and 1917 they were under Russian sovereignty and since that last year they are under Finnish sovereignty. Despite this, its inhabitants speak Swedish, are ethnically Swedish-Finnish and enjoy considerable autonomy within the political organization of Finland.

On the one hand, they have a strategic location (hence the constant dispute between Russia and Sweden) that allows control of access to the Gulf of Bothnia, which supposed in the nineteenth century, block maritime access to part of the Russian territory. On the other, the installation of a Russian military base in the archipelago represented a clear threat to Sweden. Hence, a set of treaties regulated the demilitarization and the permanent neutralization of the islands.

Before the tenth century, there is little historical data on the Åland Islands, except archaeological remains that allow inferring the early presence of Christianity and the increase of the relationship with Sweden, which culminated in 1284 with the creation of the Duchy of Finland, which included to the Islands, under the domination of that country's crown. During almost five centuries, Finland enjoyed a degree of relevant autonomy that was strengthened with its elevation to Grand Duchy in 1581 and the constitution of its Diet during the reign of Gustavo II [50].

Since its inception, the territory of Finland was the subject of disputes and wars between Swedes, Poles, Baltic countries, Germany and, mainly, Russia. Religious issues and the fear of the advance of the Russian Orthodox urged the Catholic Church to encourage the Swedes to occupy the territory. In this context, the Åland Islands were a strategic 
enclave that dominated the entrance to the Gulf of Bothnia. For this reason, they were occupied for the first time by the Russians in 1714. Through the Treaty of Nystad in 1721, Russia returned Finland and the Islands to the Swedes in exchange for Livonia, Estonia, Ingria and other territories on the Baltic Sea. However, a new conflict broke out at the beginning of the $19^{\text {th }}$ century and the Åland Islands were again the object of negotiation between the Russians and the Swedes. The former wanted control of access to the Gulf of Bothnia, while the latter did not want to deliver the islands because it left the Russians very close to the Swedish coasts. Finally, Finland and the islands were ceded to Russia through the Treaty of Frederikshamm in 1809 [50].

Between 1809 and 1917, the Åland Islands, as well as Finland, belonged to the Russian Empire as Grand Duchy. Until the end of the $19^{\text {th }}$ century, Finland enjoyed great autonomy that allowed it to have its own army, currency and parliament, although Swedish continued to be the official language on the islands, as well as its traditions. However, the transfer of the capital to Helsinki meant a break in those traditions by the emergence of a national feeling, which was reflected by the publication in 1835 of the poem Kalevala by Elias Lönnrot, inspired by popular songs, and the adoption of the Finnish language as official language, in line with Swedish, in 1863. This situation of wide autonomy would be modified with the enthronement of Nicholas II in 1894, who initiated a campaign of Russification of the territory that, except for a few years, continued with force until the independence in 1917 [50].

Russia fortified the Åland Islands, aware of its strategic relevance, which generated not only the protests of Sweden, but also of powers such as France and Great Britain. The fortifications on the islands were destroyed by Anglo-French forces during the Crimean War (1853-1856). Despite the insistence of English and French, the Swedes refused to break relations with Russia. After the defeat, the British proposed to restore Finland and the islands to the Swedes or, alternatively, grant independence to the islands under French protection. The lack of commitment of the latter country and the refusal of Russia culminated in the signing of the Convention on the Demilitarization and Neutralization of the Åland Islands [50]. This situation was ratified by several Treaties and Conventions in 1921, 1940, 1947 and 1977 [51].

The independence of Finland was proclaimed on 6 December 1917, but it was not recognized until the signing of the Treaty of Brest-Litovsk, on 3 March 1918. During that period of convulsion, the inhabitants of the Åland Islands saw the opportunity to ask for union with the Kingdom of Sweden. To this end, in August 1917, an assembly of the inhabitants of the Islands requested reunification, which was ratified by $95 \%$ of the inhabitants through a plebiscite held between December 25 and 29, 1917. The petition was transmitted to the Swedish king, but it arrived on 2 February 1918 and Sweden had already recognized the independence of Finland in January of that year. However, that country sent troops to the islands to "protect" the inhabitants on 13 February 1918. The conflicts ended with the withdrawal of Russian troops during the month of March and the Swedish in May 1918 [51]. On 14 October 1920, Finland and Russia signed the Treaty of Tartu, setting the boundaries between the two countries. Finland retained the territories that had belonged to the Grand Duchy, in addition to Petsamo, with its ice-free harbor in the Arctic Ocean.

In June 1919, the inhabitants of the Åland Islands again asked to unify with Sweden. Meanwhile, both countries negotiated a solution to the dispute through Great Britain and France. In the area of the Peace Conference in Paris, several solutions were evaluated: a) 
the creation of a condominium between Sweden and Finland; b) proclaim an independent State under the protection of the League of Nations; c) return the islands to Sweden; and d) that the islands remain under Finnish control. In the absence of agreement within the framework of the Conference, the Secretary of Foreign Affairs of Great Britain requested the intervention of the League of Nations. Finally, this international organization recognized the sovereignty of Finland on 24 June 1921, which nevertheless had to guarantee the use of the Swedish language and other aspects related to the interests of the islanders [50]. It should be noted that in that resolution, the League of Nations determined that "the principle of self-determination was not applicable" [16].

Previously, Finland had approved the Autonomy Law of the Åland Islands, which gave it an advantageous position for discussion within the League of Nations [50]. Following that resolution, Finland extended the guarantees provided to the inhabitants of the Åland Islands through the Guarantees Act of 1922, which were improved with the laws of 1952 and 1991 [52].

\section{b) Regulatory framework of autonomy}

The 1991 law regulates the relations between the Finnish State and the islands, the conflict between them, economic relations and the recognition of a regional citizenship. This law can only be reformed if it is approved by the Finnish parliament and the assembly of the islands by a special two-thirds majority. This legislation recognizes the right of the Islands to constitute an Assembly that has the power to establish its regulations and legislate on the flag and the coat of arms, the municipal administration, taxes, security, construction and urban planning, leases of land, protection of the environment, cultural and historical protection, medical and health service, education, culture, sports and youth work, museums, forests, hunting and fishing, mail, roads, commerce and any other faculty that does not correspond to the Finnish State [52].

The latter is responsible for legislating on: civil liberties, freedom of movement and expression, international relations, defense, civil law, commercial law, criminal law - with exceptions, - labor law, judicial codes and paper money. Finland can not bind the Åland Islands internationally if they do not agree. Otherwise, Finland has to reject the agreement or make a reservation about the particular situation of the islands. The laws approved by the Assembly are put to the consideration of the Alandic Delegation and, subsequently, of the Ministry of Justice. It is up to the latter to analyze if the Assembly has not exceeded the powers granted by the Autonomy Law. Then, the projects are referred to the president, who can veto them if the Assembly exceeded its powers or if they cover issues of defense or internal security. To be able to do the latter, the Supreme Court must first be consulted, although its opinion is not binding [52].

The demilitarization and neutralization of the territory does not fall within the competence of the Assembly. After the reform of the Autonomy Law of 1991, the Åland Islands have considerable autonomy in tax matters. However, it can only be established taxes at the municipal level. The Finnish government establishes national taxes, as in the rest of the provinces. The State returns part of these revenues to the Åland Islands according to a compensation index. Finally, the Åland Islands do not have international powers. However, like Greenland and the Faroe Islands of Denmark, they are represented in the Nordic Council. When Finland joined the European Union, the Åland Islands requested excep- 
tions to EU legislation, which were accepted. The Finnish Parliament and the Assembly can transfer competences mutually. The Åland Islands have a representative in the Finnish parliament. Any difference is resolved by the Supreme Court of Finland [52].

The Governor of the Islands is appointed by Finland with the agreement of the Assembly and can issue decrees on the organization of government and administration. If the regulations issued by the Finnish Government affect the Åland Islands in any way, the Assembly should be consulted. For its part, it can present initiatives in the Finnish Parliament through the Executive Branch [52].

Only people who have the right of neighborhood, have property and trade or a profession, can vote in the elections of the islands. To qualify for this right, they must be a citizen of Finland, reside in the Åland Islands for at least five years and speak the swedish language. Although Finnish and Swedish are official languages in Finland and therefore both are taught in schools. In the Åland Islands only Swedish is the official language and is the only language taught in a population where $95 \%$ is swedish-speaking [52].

\section{Final Reflections}

The Falklands Islands (Islas Malvinas), South Georgia and South Sandwich Islands with the South Atlantic and the Antarctic form a geopolitical systemic construct. For this reason, we must understand the strategic implications of this geopolitical space for the interests of that country to understand the position of the United Kingdom of Great Britain and Northern Ireland with respect to the Islands.

It is clear that British interests in the region do not relate to the wishes of the islanders. The main issue in this conflict is the licensing of exploration and exploitation of natural resources, from fishing and oil, to the extraction of rare earths and the obtaining of patents on biological diversity for pharmaceutical and other subsurface resources maritime [53]. Also, the control of the South Atlantic and the Antarctic are essential for the United Kingdom.

Considering these factors, and taking into account that the Antarctic Treaty is an agreement that covers the entire world, the Argentine strategy of turning the Malvinas question into a South American and global issue has been successful. In the near future, by its very nature, the Madrid Protocol to the Antarctic Treaty will have to be renegotiated and that country could even include the problem of the Malvinas, South Georgia and South Sandwich Islands within its agenda.

Although the strategic situation of the Åland Islands and the Malvinas are comparable, the actors in dispute are not: Sweden vs. Finland and Argentina vs. United Kingdom of Great Britain and Northern Ireland. However, in the context of the crisis unleashed by the departure of the United Kingdom from the European Union, there are some lessons that can be drawn from the conflict in the Åland Islands.

Firstly, Argentina must continue to strengthen diplomatic action through the regionalization of the conflict, emphasizing how the presence of an extraregional power affects the strategic resources of the entire region. In addition, this country should reinforce its physical presence strengthening the infrastructure in Patagonia and especially in Tierra del Fuego as a gateway to the Antarctic (for example, to move forward with the establishment of a Logistic Pole in Ushuaia), qualitatively increase the presence in that continent (for example, creating a Logistics Center in Marambio or Petrel Establishments) and in the South Atlantic. The Argentine National Defense system should also contribute by adapting its deployment to 
this vision, changing the center of gravity towards the south, which will become increasingly relevant as the $21^{\text {st }}$ century passes, reopening - among other measures - the Air Brigade in the city of Río Gallegos. In this last suggestion, the defense system will keep strategic attitude until United Kingdom and Argentina sign an agreement.

Secondly, Argentina undertook to respect the interests of the islanders. For this, the argentine federal's organization has much more to offer to the islanders than the category of "overseas territory", especially taking into account that in the context of the Brexit they would lose access to the European Union market. In this sense, the Autonomous Province of the Malvinas Islands could be created, which includes the Malvinas Islands, Georgia and Sandwiches del Sur, with a differentiated status to that of the Argentine provinces and the Autonomous City of Buenos Aires, in order to respect its customs, its education system, its language and even the management of its natural resources (prerogatives of the federal system of Argentina). In this sense, the measures adopted by the Argentine government in the 1970s, regarding the granting of scholarships or health services to the inhabitants of the islands, could be reimplemented. Additionally, the demilitarization and neutralization of the islands in perpetuity can be agreed with the United Kingdom from the treaty within two countries will be signed.

To implement what is indicated above, based on the provisions of Article 2 of Law No. 23,775 of May 10, 1990, partially amended by Law No. 26,552 of December 11, 2009, the National Congress of the Republic Argentina must enact a Law of Autonomy of the Malvinas Islands, South Georgia Islands and South Sandwich Islands that provides, without being exhaustive, the following provisions:

- Recognize the Malvinas as a nation within the Argentine State, following the model of Quebec in Canada and that of the Åland Islands.

- Accept the toponymy islanders on the islands.

- Establish the English language as the official language of the Malvinas, Georgia and South Sandwich Islands.

- Choose a parliament that has powers similar to those of the provinces in terms of primary and secondary education, health, security, local tax, criminal law and criminal procedure (following the Anglo-Saxon tradition), the creation of a judicial power and a penitentiary system.

- Grant the islanders the right to exploit rights over natural resources in their territory.

- Choose a governor. Both this election and that of parliamentarians would be governed by local laws, as long as they respect the democratic and republican form of government.

- Cede the defense, international relations and federal justice to the Argentine Republic.

- Choose two senators and three deputies for the National Congress.

- Grant the right, once the treaty was signed and the islands incorporated into the Argentine State, elected the local legislature and the governor, to propose modifications to that Autonomy Law that must be endorsed by the National Congress.

- It will be e Treaty between Argentina and United Kingdon where will be ratified the previous points and established: 1 . The Islanders could be opted to independence 
50 years after the treaty or in case that coup d'etat overthrow the democratic regime, and, 2. Both Argentina and the United Kingdom will reserve that the signature of this Treaty does not imply any waiver of the sovereign claims that both countries have over Antarctica, and they mutually recognize the right to use the projection of the islands as one of the arguments to legitimize their rights on that continent.

\section{References}

1. Eissa, S. (2005), Hielos Continentales. Las variables internas en la política exterior argentina [Ice Continent. The internal variables in Argentine foreign policy], Fundación Síntesis, Santiago de Chile, Chile.

2. Paradiso, J. (1996), Debates y trayectoria de la politica exterior Argentina [Debates and trajectory of the Argentine foreign policy], Grupo Editor Latinoamericano, Buenos Aires, Argentina.

3. Eissa, S. (2015), ¿La irrelevancia de los Estados Unidos? La política de defensa argentina (1983-2010) [The irrelevance of the United States? The Argentine defensa policy (1983-2010)], Arte y Parte, Buenos Aires, Argentina.

4. Malamud, C. (2018), "El mundo de Trump al que Macri no quería llegar es el que lo tiene en el pulmotor" [The world of Trump that Macri did not want to reach is the one that has it in the pulmotor], El Cronista, November 30, available at: in https://www.cronista.com/3dias/Malamud-El-mundo-de-Trump-al-queMacri-no-queria-llegar-es-el-que-lo-tiene-en-el-pulmotor-20181130-0002.html (accessed: 06.12.2018).

5. Chuter, A. (2018), "Auditors say Britain can't afford its 10-year defense equipment plan", Defensenews, January 31, available at: https://www.defensenews.com/global/europe/2018/02/01/auditors-say-britaincant-afford-its-10-year-defense-equipment-plan/ (accessed: 06.12.2018).

6. "How Britain changed its focus from defense to welfare and health" (2017), The Telegraph, December 24, available at: https://www.telegraph.co.uk/news/2017/12/24/britain-changed-focus-defence-welfarehealth/ (accessed: 06.12.2018).

7. "British missiles aim to Tierra del Fuego in Argentina" (2018), Hispan TV, available at: https://www. hispantv.com/noticias/argentina/378922/misiles-britanicos-otan-islas-malvinas (accessed: 06.12.2018).

8. Stone, J. (2018), "Brexit: Falkland Islands government sounds alarm on leaving single market", Independent, May 12, available at: https://www.independent.co.uk/news/uk/politics/brexit-falklands-islandssingle-market-trade-eu-fishing-loligo-squid-government-a8347696.html (accessed: 06.12.2018).

9. Klare, M. (2001), "La nueva geografía de los conflictos internacionales" [The new geography of international conflicts], Foreign Affairs en español, no. 2 (1), pp. 151-165.

10. Caplan, S. and Eissa, S. (2015), "Análisis estratégico del Sistema Malvinas, Antártida y Atlántico Sur" [Strategic analysis of Malvinas, Antarctica and South Atlantic System], Series Documentos de Trabajo de la Universidad de la Defensa Nacional, no. 28.

11. Beck, P. (1985), "The future of the Falkland Islands: a solution made in Hong Kong", International Affairs, no. 4, vol. 61, pp. 643-660.

12. Beck, P. (1988), The Falkland Islands As An International Problem, Routledge \& Chapman and Hall Inc., London, UK.

13. Laver, P. (2001), The Falklands/Malvinas Case: Breaking the Deadlock in the Anglo-Argentine Sovereignty Dispute, Martinus Nijhoff, The Hague, Netherlands.

14. Kozloski,Ch. (1996), "Nationalism and the Falkland Islands War", Political Geography, 425-G, available at: http://www.mindspring.com/ koz/papers/FalklandPaper.html (accessed: 06.12.2018).

15. Núñez, J. (2010), Shared sovereignty: the Malvinas Islands. Paper presented at V Congreso de Relaciones Internacionales, available at: http://www.iri.edu.ar/publicaciones_iri/IRI \%20COMPLETO \%20- \%20 Publicaciones-V05/Publicaciones/cd \%20V \%20congreso/ponencias/0 \%20Nu \%F1ez, \%20Jorge_Soberan \%EDa \%20compartida_Malvinas.pdf (accessed: 06.12.2018).

16. Kohen, M. (1986), "Alternativas para la solucion del conflicto por las islas Malvinas" [Alternatives to the solution about the conflict in the Islas Malvinas], Revista de Estudios Internacionales, vol. 7, no. 4, available at: http://www.cepc.gob.es/gl/publicaci \%C3 \%B3ns/revistas/acceso-ao-fondo-historicode-revistas?IDR=14\&IDN=1225 (accessed: 06.12.2018).

17. Willetts, P. (2012), "Distributed sovereignty and the Falkland Islands, (Malvinas Islands) dispute", South Atlantic Council Occasional Papers, no. 11, available at: http://www.staff.city.ac.uk/p.willetts/SAC/OP/ OCCPAP11.PDF (accessed: 06.12.2018).

18. Bullock, D. and Mitchell, Ch. (1987), "The Åland Island solution”, South Atlantic Council Occasional Papers, no. 3, available at: http://www.staff.city.ac.uk/p.willetts/SAC/OP/OCCPAP03.PDF (accessed: 06.12.2018). 
19. Hofstede, G. (2001), Culture's Consequences: Comparing Values, Behaviour, Institutions, and Organizations across Nations, Sage, London, UK.

20. Vespucio, A. (1951), El nuevo mundo-Cartas relativas a sus viajes y descubrimientos [The new world. Letters related to his travel and discoveries], Editorial Nova, Buenos Aires, Argentina.

21. Von Wieser, F. (1902), Die Karten von America in dem Islario General des Alonso de Santa Cruz, Cosmógrafo mayor des Kaiser Karl $V$ [The maps of America in the Islario General of Alonso de Santa Cruz, Major Cosmograph of the Emperor Charles V], Wagner'schen Universitäts-Buchhandlung, Innsbruck, Germany.

22. Allardyce, W. (1909), The story of Falkland Islands. Being an account of their discovery and early history (1500-1842), The Government Printing Office by William Worthy, Port Stanley, available at: https:// www.fig.gov.fk/archives/jdownloads/People/Culture \%20and \%20Early \%20History/The \%20Story \%20 of \%20the \%20Falkland \%20Islands \%20by \%20W \%20L \%20Allardyce \%20- \%201909.pdf $\quad$ (accessed: 06.12.2018).

23. Quellet, R. (1982), Historia política de las Islas Malvinas [Political history of the Islas Malvinas] Escuela Superior de Guerra Aérea, Buenos Aires, Argentina.

24. "A key document" (1982), El País, May 12, available at: https://elpais.com/diario/1982/05/12/internacional/390002403_850215.html (accessed: 06.12.2018).

25. Lorenz, F. (2014), Todo lo que necesitás saber sobre Malvinas [All you need to know about Malvinas], Paidós, Buenos Aires, Argentina.

26. Dinatale, M. (2018), "Malvinas: Archivo General de las Indias certificó más documentos que sustentan la soberanía la Argentina" [Malvinas: General Archive of the Indies certified more documents that support the sovereignty of Argentina], Infobae, November 3, available at: https://www.infobae.com/ politica/2018/11/03/malvinas-el-archivo-general-de-indias-certifico-mas-documentos-que-sustentan-lasoberania-de-la-argentina/ (accessed: 06.12.2018).

27. Delgado, C. (2011), Cuestión Malvinas. Atlántico Sur, Plataforma Continental y Antártida. Propuesta para la construcción de una política de estado [Malvinas Issue. South Atlantic, Continental Plate and Antarctica. Proposal for the construction of a state policy], Master Thesis of the Instituto de Relaciones Internacionales (IRI) of the Universidad Nacional de la Plata, available at: http://www.iri.edu.ar/images/ Documentos/maestria/tesis/tesis_biangardi.pdf (accessed: 06.12.2018).

28. Valega, A. (2004), "El utti possidetis y la Corte Internacional de Justicia" [The utti possidetis and the International Court of Justice], Revista de Derecho, no. 21, pp. 131-138.

29. Escudé, C. and Cisneros, A. (2000), Historia General de las Relaciones Exteriores de la República Argentina [General history of the external relations of the Argentina Republic], GEL \& CARI, Buenos Aires, availabale at: http://www.argentina-rree.com/historia.htm (accessed: 06.12.2018).

30. Warnick, Sh. (2008), The reluctant colonization of the Falkland Islands, 1833-1851: a study of British Imperialism in the Southwest Atlantic, Master Thesis of the University of Richmond, available at: https:// scholarship.richmond.edu/cgi/viewcontent.cgi?referer=https://www.google.com/\&httpsredir=1\&article=1 703\&context=masters-theses (accessed: 06.12.2018).

31. Mamani, C. and Cortez, F. (2017), "La lucha por el reconocimiento. La independencia argentina en el marco de las relaciones internacionales (1816-1850)" [The struggle of recognition. Argentine Independence in the framework of international relations (1816-1850)], Revista de Historia Americana y Argentina, no. 2, vol. 52, availble at: http://revistas.uncu.edu.ar/ojs/index.php/revihistoriargenyame/article/ view/1212(accessed: 06.12.2018).

32. Hobsbawm, E. (1998), The impire era, 1875-1914 [The era of empires, 1875-1914], Crítica, Barcelona, Spain.

33. Jastreblansky, M. (2012), “La propuesta secreta de los ingleses a Perón por las Malvinas" [The secret proposal of the Britishs to Perón about Malvinas], La Nación, March 29, available at: http://www.lanacion. com.ar/1455991-la-propuesta-secreta-de-los-ingleses-a-peron-por-las-malvinas (accessed: 06.12.2018).

34. Machuca, Ch. (2001), "Malvinas: el acuerdo del 14 de julio de 1999" [Malvinas: the agreement of 14 July 1999], Boletín del Centro Naval, no. 119, available at: http://www.centronaval.org.ar/boletin/ BCN803/803machuca.pdf (accessed: 06.12.2018).

35. "Las Malvinas en la era kirchnerista" [The Malvinas in the Kirshner's era] (2016), Telesur TV (June 10), available at: https://www.telesurtv.net/news/Las-Malvinas-en-la-era-kirchnerista-20160530-0020.html (accessed: 06.12.2018).

36. Bologna, B. (2011), "Un límite efectivo al despojo" [An effective limit to dispossession], Miradas al Sur, September 25.

37. Bragger, S. and Gyford S. (2007), "Las Islas Malvinas 25 años después" [The Islas Malvinas 25 years later], Cafebabel.es, June 13, available at: https://cafebabel.com/es/article/las-islas-malvinas-25-anos-despues-5ae0066bf723b35a145e0a8c/ (accessed: 06.12.2018). 
38. "República Argentina - Poder Ejecutivo Nacional" [S.a.], Words of the President of the Argentina Nation Cristina Fernández in the MERCOSUR Summit. Reception of the Presidency Pro-Tempore of MERCOSUR, in Montevideo, Uruguay, available at: presidencia.gov.ar (accessed: 06.12.2018).

39. "Malvinas: reacción británica por la decisión del MERCOSUR" [Malvinas: British reaction related to MERCOSUR decision] (2011), Tiempo Argentino, December 22.

40. Puceiro, I. (2016), "Midieron bien y resulta que la Argentina es más grande" They measured well and it turns out Argentina is bigger”, Infobae, March 28, available at: http://www.infobae.com/2016/03/28/1800093midieron-bien-y-resulta-que-la-argentina-es-mas-grande (accessed: 06.12.2018).

41. Dinatale, M. (2016), "Aval de la ONU a un planteo argentino sobre Malvinas" [Guarantee of the UN to Argentine proposal about Malvinas], La Nación, March 27, available at: http://www.lanacion.com. ar/1883478-aval-de-la-onu-a-un-planteo-argentino-sobre-malvinas (accessed: 06.12.2018).

42. Gian, D. (2018), "Las Malvinas y Macri: la soberanía puede esperar" [The Malvinas and Macri: the sovereignty can wait], Revista Noticias, April 7, available at: http://noticias.perfil.com/2018/04/07/las-malvinas-y-macri-la-soberania-puede-esperar/ (accessed: 06.12.2018).

43. Larraquy, M. (2016), "Las ideas que maneja el gobierno para las Islas Malvinas" [The ideas of the government about Islas Malvinas], Clarín, February 6, available at: http://www.clarin.com/politica/MalvinasFalklands-Argentina-Gran_Bretana-Macri-Cameron_0_1517848645.html (accessed: 06.12.2018).

44. Mastropierro, O. (2016), "El gobierno de Mauricio Macri y la cuestión de las Islas Malvinas" [The Mauricio Macri's government and the Islas Malvinas issue], VIII Congress of International Relations, Instituto de Relaciones Internacionales de la Universidad Nacional de La Plata, La Plata, Argentina.

45. "En vez de ositos les compramos armas" [Instead of teddy bears web y them weapons] (2018), Página 12, June 28, available at: https://www.pagina12.com.ar/124705-en-vez-de-ositos-les-compramos-armas (accessed: 06.12.2018).

46. Dinatale, M. (2013), "Los isleños preparan una ofensiva diplomática para capitalizar el referéndum" [The islanders prepare a diplomatic offensive to capitalize the referendum], La Nación, March 13, avaialble at: https://www.lanacion.com.ar/1562568-los-islenos-preparan-una-ofensiva-diplomatica-para-capitalizarel-referendum (accessed: 06.12.2018).

47. "Rechazos al referéndum en las Malvinas" [Rejections to Malvinas referendum] (2013), Página 12, March 9, available at: https://www.pagina12.com.ar/diario/elpais/1-215428-2013-03-09.html (accessed: 06.12.2018).

48. "Un tribunal inglés falló en contra del derecho a la autodeterminación" [A British court ruled against the right of self-determination] (2013), Infobae, June 11, available at: https://www.infobae. com/2013/06/11/715033-un-tribunal-ingles-fallo-contra-del-derecho-la-autodeterminacion/ (accessed: 06.12.2018).

49. "ONU reiteró apoyo a Argentina para que se retome el dialogo por Malvinas" [UN reiterated support to Argentina to resume dialogue about Malvinas] (2013), Infobae, June 20.

50. Sakshaug, E. (1969), Aspects of the Åland Islands question, Portland State University University, Portland, USA.

51. Hannikainen, L. (1994), The continued validity of the demilitarized and neutralized status of the Aland Islands, available at: http://zaoerv.de/54_1994/54_1994_3_4_a_614_651.pdf (accessed: 06.12.2018).

52. Hannikainen, L. (2013), "La autonomía en Finlandia: la autonomía territorial de las islas Åland y la autonomía cultural del pueblo indígena Saami" [The autonomy in Finland: the territorial autonomy of the Åland Islands and the cultural autonomy of Saami people], Revista d'Estudis Autonòmics i Federals, no. 17, available at: http://www.raco.cat/index.php/REAF/index (accessed: 06.12.2018).

53. Recce, J. (2012), "Una nueva identidad estratégica nacional: Argentina país Austral, Suramericano y Emergente" [A new national strategic identity: Argentina austral country, South American and emergence], Argentina en Asuntos Estratégicos, no. 1, pp. 37-48.

Received: December 13, 2018 Accepted: February 14, 2019

Author's information:

Eissa Sergio Gabriel — PhD (Political Science), Professor; seissa@yahoo.com 